\title{
PENGARUH PEMBERIAN JAMUR Fusarium graminearum TERHADAP HISTOPATOLOGI TUBULUS SEMINIFERUS MENCIT (Mus musculus)
}

\author{
THE EFFECT OF Fusarium graminearum EXPOSURE OF \\ THE SEMINIFEROUS TUBULES HISTOPATHOLOGICAL \\ OF MICE (Mus musculus)
}

\author{
Fierda Kabayo ${ }^{1)}$, *Abdul Samik ${ }^{2)}$, Soeharsono ${ }^{3)}$, Ismudiono ${ }^{2)}$, Hani Plumeriastuti ${ }^{4}$, \\ Tjuk Imam Restiadi ${ }^{2}$ \\ ${ }^{1)}$ Student, ${ }^{2)}$ Department of Veterinary Reproduction, ${ }^{3)}$ Department of Veterinary Anatomy, \\ ${ }^{4)}$ Department of Veterinary Pathology \\ Faculty of Veterinary Medicine, Universitas Airlangga \\ *Corresponding author: samik_s3yahoo.co.id
}

\begin{abstract}
The aim of this research was to show the influence of seminiferous tubules histopathology of mice (Mus musculus) caused Fusarium graminearumexposure. This research was done in April-May 2017 in Microbilogy Laboratory Faculty of Science and Technology, Animal Laboratory, and Microbilogy Laboratory Faculty of Veterinary Medicine UniversitasAirlangga. This research used 20 male mice (Mus musculus) aged 6 weeks with 18-30 gram body weight. The mice devided into four groups: P0 given 0,25 ml Sodium chloride without Fusarium graminearum exposure by oral; P1 given $0,25 \mathrm{ml}$ Fusarium graminearum exposure with dilution $10^{2}$ by oral; $\mathrm{P} 2$ given $0,25 \mathrm{ml}$ Fusarium graminearum exposure with dilution $10^{3}$ by oral; and P3 given $0,25 \mathrm{ml}$ Fusarium graminearum exposure with dilution $10^{4}$ by oral. This treatment carried out for 21 days. Each milliliter dilution containing $228 \times 10^{6}$ spore for P1, $228 \times 10^{7}$ spore for $\mathrm{P} 2$, and $228 \times 10^{8}$ spore for $\mathrm{P} 3$. Then do the surgery and harvesting the testes then performed histopathological examination by scoring of seminiferous tubules. For data analyzing used non parametric difference Kruskall-Wallis and continued with Mann-Whitney. The result of this research was showed that decreased the spermatogenic cells in the process of spermatogenesis significant.
\end{abstract}

Key words : Fusarium graminearum, zearalenone, seminiferous tubules, mice, Mus musculus.

\section{Pendahuluan}

Pakan merupakan salah satu hal penting dalam pemeliharaan hewan ternak (Pahlevi, 2014). Komponen utama penyusun pakan adalah biji-bijian seperti jagung. Jagung memiliki keunggulan dibandingkan dengan bahan pakan lainnya, yakni sebagai pakan yang mengandung sumber energi. Jagung memiliki kandungan Energi Metabolisme $3370 \mathrm{Kkal} / \mathrm{kg}$, Protein Kasar 8,6\% dan Lemak Kasar 3,9\% (Umiyasih dan Wina, 2008).

Banyak kendala yang dihadapi oleh petani jagung dalam negeri pasca panen, diantaranya kontaminasi jagung oleh kotoran dan jamur. Penyimpanan jagung yang kurang tepat sangat berpengaruh terhadap kualitas jagung. Berikut adalah beberapa faktor akibat penyimpanan jagung yang kurang baik yaitu jagung dapat terserang serangga, mikroorganisme dan tikus, hal tersebut merupakan penyebab kerusakan utama pada jagung. Serangga tersebut dapat melukai biji jagung sekaligus menyebarkan jamur dengan cara membawa spora jamur pada permukaan tongkol jagung. Selain itu, aktivitas metabolisme serangga dapat menyebabkan kenaikan kadar air substrat yang selanjutnya memicu pertumbuhan jamur. Salah satu spesies jamur yang sering menyerang jagung salah satunya adalah Fusarium graminearum. (Surtikanti, 2011).

Fusarium graminearum memproduksi dan mensekresi beberapa mikotoksin seperti zearalenon (ZEA) dan deoxynivalenol (DON) yang merupakan resorcylic acid lactone yang mempunyai efek estrogenik (Geraldo, et al., 2004).

Zearalenon (ZEA) merupakan mycoestrogen (phytoestrogen) yang diproduksi 
oleh berbagai jamur dari genus Fusarium. Terutama Fusarium graminerum, dapat meningkatkan kadar hormon estrogen sehingga dapat menimbulkan gangguan siklus reproduksi (Maragos, 2010). Beberapa efek estrogenik tersebut seperti penurunan fertilitas, peningkatan embrioethal, penurunan berat kelenjar adrenal, pituitary, serta tiroid. Selain itu dapat menyebabkan perubahan kadar serum progesterone dan estradiol (Widiyono et al,. 2011). Zearalenon penyebab ovarium dystrophy dan absorbspada wanita yang makannya tercemar dengan jamur yang mengandung zearalenon, sementara itu pada testis juga dapat menyebabkan dystrophy dan meningkatkan ukuran.

Deoxynivalenol (DON) merupakan mikotoksin yang dihasilkan oleh jamur Fusarium graminearum, yang dikenal sebagai vomitoxin. Protein sintesis Deoxynivalenol juga dapat menyebabkan gangguan reproduksi berupa penurunan oosit dan mengganggu perkembangan embrio (Maryam, 2007).

Selama ini informasi mengenai bahaya jamur Fusarium graminearum yang menyerang jagung terhadap organ reproduksi jantan belum banyak diketahui masyarakat. Oleh karena itu perlu dilakukan penelitian mengenai pengaruh paparan jamur Fusarium graminearum terhadap gambaran histopatologi tubulus seminiferus mencit (Mus musculus).

\section{Materi dan Metode Penelitian Materi Penelitian}

Hewan coba yang digunakan yaitu 20 ekor mencit (Mus musculus) jantan dewasa berumur 6 minggu dengan berat badan berkisar 18-30 gram, sehat dengan ciri-ciri bulu halus, mata bersinar, tidak ada bekas luka, tidak pincang, dan belum pernah digunakan untuk penelitian lain.

Penelitian ini menggunakan empat perlakuan sehingga didapatkan jumlah ulangan 4,75 yang dibulatkan menjadi 5 ulangan. Untuk mengantisipasi kematian mencit maka jumlah mencit dilebihkan 50\% menjadi delapan mencit atau ulangan dalam setiap perlakuan.

\section{Alat dan Bahan Penelitian}

Alat yang digunakan yaitu kandang box yang terbuat dari plastik, kawat penutup, tempat pakan dan minum mencit, tabung erlenmeyer, gelas ukur, tabung reaksi, api Bunsen, tabung sentrifugasi, cawan petri, ose, object glass, cover glass pipet tetes, pipet Vinmed ${ }^{\circledR}$, bulb pump, timbangan digital, autoclave, centrifuge, haemocytometer, spektrofotometer, dan mikroskop Olympus ${ }^{\circledR}$ CX-41. Sedangkan untuk pembedahan mencit menggunakan dissectting set dan papan seksi. Perlakuan pada mencit manggunakan jarum sonde lambung dan spuit Terumo syringe ${ }^{\circledR}$.

Bahan yang digunakan untuk pemeliharaan mencit yaitu air minum (ad libitum), pakan mencit pellet 511 (PT. Charoen Pokphand Surabaya). Jagung yang telah diinkubasi hingga ditumbuhi jamur. Bahan untuk media pertumbuhan jamur peptone $15 \mathrm{~g}$, agar-agar powder $15 \mathrm{~g}, \mathrm{MgSO}_{4} 1 \mathrm{~g}$, $\mathrm{KH}_{2} \mathrm{PO}_{4} 0,5 \mathrm{~g}$, Malachite green oxalate 2,5 $\mathrm{mg}$, distilled water 1 liter, Nutrient Broth, Sodium Chloride. Bahan untuk melakukan pembedahan jaringan antara lain formalin $10 \%$. Serta reagen untuk pembuatan preparat histopatologi yaitu alkohol $70 \%, 80 \%$, 90\%, 95\%, xylol, paraffin, Canada balsam, dan pewarnaan HE.

\section{Metode Penelitian \\ Sterilisasi Alat dan Bahan}

Sebelum penelitian ini dimulai, alat dan bahan disterilkan terlebih dahulu. Untuk alat-alat gelas dan cawan petri dicuci terlebih dahulu kemudian di keringkan. Alat dan bahan tersebut kemudian dibungkus dan dimasukkan ke dalam autoklaf pada suhu $121^{\circ} \mathrm{C}$ dengan tekanan 15 psi selama 15 menit.

\section{Pembuatan Media}

Pembuatan media selektif untuk F.graminearum yaitu dengan menggunakan Malachite Green Agar 2,5+ (MGA). Bahan untuk membuat media MGA 2,5+ yaitu peptone $15 \mathrm{~g}$, agar-agar powder $15 \mathrm{~g}$, $\mathrm{MgSO}_{4} 1 \mathrm{~g}, \mathrm{KH}_{2} \mathrm{PO}_{4} 0,5 \mathrm{~g}$, Malachite green oxalate 2,5 mg, semua bahan dicampur dan dilarutkan dengan destilled water hingga 1 liter kemudian dipanaskan hingga larut sempurna lalu disterilkan dalam autoklaf pada suhu $121^{\circ} \mathrm{C}$ selama 15 menit. (Thompson, et al., 2013). Pembuatan media dilaksanakan di Laboratorium Mikrobiologi Fakultas Sains dan Teknologi Universitas Airlangga. 


\section{Inkubasi Jagung}

Biji jagung didapatkan dari dua buah jagung yang telah dirontokkan kemudian disinfektan dengan $\mathrm{NaOCl}$ (Sodium hipoklorit) $0,5,1$ atau $1,5 \%$ selama $1,3,5$ atau 10 menit, dibilas tiga kali dengan air steril kemudian diletakkan pada kertas kering steril dalam laminar. Didapatkan perlakuan terbaik, yaitu $\mathrm{NaOCl} 1 \%$ selama 5 menit, digunakan untuk mensterilkan dua ratus biji jagung dari masing-masing dua kultivar jagung. Secara aseptis biji jagung diletakkan pada media MgA dilengkapi dengan potongan daun anyelir steril. Dalam $90 \mathrm{~mm}$ Petri-dish (1 di pusat dan 1 di masing-masing kuadran) diletakkan 5 biji jagung. Biji jagung diinkubasi selama 7 hari pada $25^{\circ} \mathrm{C}$. Pertumbuhan sporulasi dan hasil diamati dan direkam pada hari 4 dan 7 masa inkubasi (Thompson et al,. 2013)

\section{Penanaman Koloni pada Media Nutrient Broth}

Penanaman koloni pada media nutrient broth bertujuan untuk memindahkan koloni jamur dari media agar ke media cair, serta untuk perbanyakan mikroorganisme dalam jumlah besar. Media ini merupakan media kultur dasar yang digunakan untuk menjaga mikroorganisme. Komposisi media nutrient broth antara lain pepton 10 gram, $\mathrm{NaCl}$ fisiologis 5 gram, beef extract 3 gram. Seluruh bahan dilarutkan dan dipanaskan dalam $1000 \mathrm{ml}$ aquades steril dalam beaker glass dengan cara diaduk. Diatur $\mathrm{pH}$ berkisar $\pm 7,2$ dan dibiarkan hingga mendidih dan homogen. Kemudian di sterilkan dengan autoclave 1,5 atm selama 15 menit (Himedia, 2011)..

Media nutrient broth yang telah di sterilkan tersebut, dipindahkan sebanyak 50 $\mathrm{ml}$ ke dalam tabung reaksi berukuran 100 ml. Kemudian, dilakukan pengambilan miselium menggunakan jarum inokulasi (ose) dari biakan jamur Fusarium graminearum yang telah diperiksa sebelumnya, pindahkan ke dalam media nutrient broth tersebut. Suspensi media tersebut dihomogenkan dengan vortex. Setelah selesai, tutup tabung reaksi menggunakan kapas dan aluminium foil dan inkubasi dalam suhu ruang selama 7 hari. Setelah 7 hari, dilakukan pengamatan adanya miselium yang tumbuh pada media tersebut.

\section{Pengenceran Suspensi Jamur Fusarium} graminearum
Setelah 7 hari melakukan pengamatan, adakah muncul miselium pada media $n u$ trient broth tersebut. Lalu, pindahkan $10 \mathrm{ml}$ dari suspensi media tersebut ke dalam tabung reaksi. Untuk menghomogenkan kembali suspensi tersebut, vortex selama beberapa detik. Agar didapatkan endapan dari suspensi tersebut, centrifuge dengan kecepatan $6000 \mathrm{rpm}$ selama 15 menit. Apabila telah selesai, buang supernatan, sisakan 1 ml pada tabung reaksi lalu tambahkan $\mathrm{NaCl}$ fisiologis sebanyak $9 \mathrm{ml}$ untuk memulai pengenceran, dan vortex agar suspensi tersebut homogen.

\section{Persiapan Hewan Coba}

Penelitian ini menggunakan hewan coba berupa mencit (Mus musculus) jantan berjumlah 20 ekor yang akan dibagi menjadi 4 perlakuan yaitu $\mathrm{P} 0, \mathrm{P} 1, \mathrm{P} 2$, dan P3. Sebelum dilakukan perlakuan, mencit terlebih dahulu diadaptasikan selama tujuh hari serta diletakkan didalam kandang box plastik dengan penutup kawat. Kandang dialasi dengan menggunakan sekam dan diganti setiap lima hari sekali. Mencit dipelihara dengan diberikan pakan dan minum ad libitum.

\section{Perlakuan}

Mencit (Mus musculus) jantan diambil secara acak dan dibagi dalam empat perlakuan. Setiap perlakuan terdiri dari 5 ekor mencit. Perlakuan terhadap hewan coba terdiri atas P0, P1, P2, dan P3. Setiap perlakuan diberikan dosis $0,25 \mathrm{ml} / \mathrm{ekor} / \mathrm{hari}$ dengan pelarut $0,25 \mathrm{ml}$ aquades, suspensi jamur $F$. graminearum dengan pengenceran berbeda pada tiap perlakuannya. Paparan diberikan selama 21 hari.

P0 : 5 mencit jantan tanpa paparan jamur Fusarium graminearum, diberikan $0,25 \mathrm{ml} \mathrm{NaCL}$ fisiologis setiap hari, pakan dan minum ad libitum selama 21 hari. Kemudian diambil tubulus seminiferusnya pada hari ke-22.

P1 : 5 mencit jantan dipapar jamur Fusarium graminearum, pengenceran $10^{2}$ sebanyak $0,25 \mathrm{ml} /$ ekor/hari serta diberikan pakan konsentrat dan ad libitum selama 21 hari. Kemudian diambil tubulus seminiferusnya pada hari ke-22.

P2 : 5 mencit jantan dipapar jamur Fusarium graminearum, pengenceran $10^{3}$ sebanyak $0,25 \mathrm{ml} /$ ekor/hari serta diberikan pakan konsentrat dan 
ad libitum selama 21 hari. Kemudian diambil tubulus seminiferusnya pada hari ke-22.

P3 : 5 mencit jantan dipapar jamur Fusarium graminearum, pengenceran $10^{4}$ sebanyak $0,25 \mathrm{ml} /$ ekor/hari serta diberikan pakan konsentrat dan ad libitum selama 21 hari. Kemudian diambil tubulus seminiferusnya pada hari ke-22.

Teknik Pengumpulan Sampel dan Pembuatan Preparat Histopatologi

Dilakukan nekropsi guna pengambilan organ testis mencit yang dilaksanakan di hari ke-22. Nekropsi dengan cepat untuk mengambil tubulus seminiferus yang berada didalam testis menggunakan scalpel. Pembedahan dimulai dari membuka skrotum hingga tampak testis. Testis diangkat dengan memotong duktus epididimis. Setelah dikeluarkan, testis dibersihkan dari jaringan ikat dan lemak. Dilanjutkan kemudian dengan disimpan dalam pot organ yang berisi larutan formalin $10 \%$ untuk selanjutnya dibuat menjadi preparat histopatologi. Pembuatan sediaan histopatologi ini dilakukan di laboratorium Patologi Veteriner Fakultas Kedokteran Hewan Universitas Airlangga.

\section{Pemeriksaan Preparat Histopatologi}

Pengamatan secara mikroskopis preparat histopatologi testis mencit menggunakan mikroskop cahaya dengan perbesaran 100x, 400x, dan 1000x. Pengamatan dan penelitian perubahan histopatologi dilakukan pada lima lapangan pandang yang berbeda dimulai dari sudut kiri atas, kanan atas, kiri bawah, kanan bawah, serta bagian tengah dari preparat histopatologi (Legowo $d k k$. 2008). Penilaian gambar histopatologi dilanjutkan dengan skoring tubulus seminiferus menggunakan Johnsen's score 9-1 untuk tubulus seminiferus abnormal (Johnsen, 1970) kemudian dimodifikasi dengan penambahan satu kategori spermatogenesis normal dengan skor 10 .

\section{Hasil}

Pengaruh pemberian jamur Fusarium graminearum terhadap tubulus seminiferus mencit memberikan pengaruh yang sangat nyata $(\mathrm{p}<0,01)$. Hasil peringkat gambaran tubulus seminiferus yang diberi paparan jamur Fusarium graminearum disajikan oleh (Tabel 1.).

Seperti yang terlihat dalam tabel 4.1 P0 berbeda sangat nyata terhadap P1, P2 dan P3 $\quad(\mathrm{p}<0,01)$. Demikian pula skoring pemberian jamur Fusarium graminearum P1 berbeda sangat nyata terhadap baik P2 maupun P3 $(\mathrm{p}<0,01), \mathrm{P} 2$ berbeda sangat nyata terhadap $\mathrm{P} 3$.

Tubulus seminiferus berbentuk bulat sampai oval dan terdapat sel-sel spermatogenik. Sel-sel spermatogenik dapat dibedakan menurut letak, warna, dan ukurannya untuk menentukkan jenis sel tersebut mulai dari spermatogonia, spermatosit, spermatid muda, spermatid tua, sampai spermatozoa. Inilah bentuk kerusakan yang disebabkan jamur fusarium graminearum disajikan oleh (Gambar 1).

Gambar 1 A menunjukan skor 9 (spermatogenesis sedikit terganggu, kerusakan epitel, banyak spermatid tua; B menunjukan skor 8 (kurang dari 5 spermatozoa per

Tabel 1. Skoring tubulus seminiferus mencit perlakuan dari pemberian jamur Fusarium graminearum.

\begin{tabular}{cc}
\hline Perlakuan & Mean \pm SD \\
\hline P0 & $81.50^{\mathrm{a}} \pm 8.15$ \\
P1 & $61.22^{\mathrm{b}} \pm 6.122$ \\
P2 & $46.56^{\mathrm{c}} \pm 4.656$ \\
P3 & $13.72^{\mathrm{d}} \pm 1.372$ \\
\hline
\end{tabular}

Keterangan : Superskrip yang berbeda pada kolom yang sama menunjukkan berbeda nyata $(\mathrm{p}<0,01)$. 

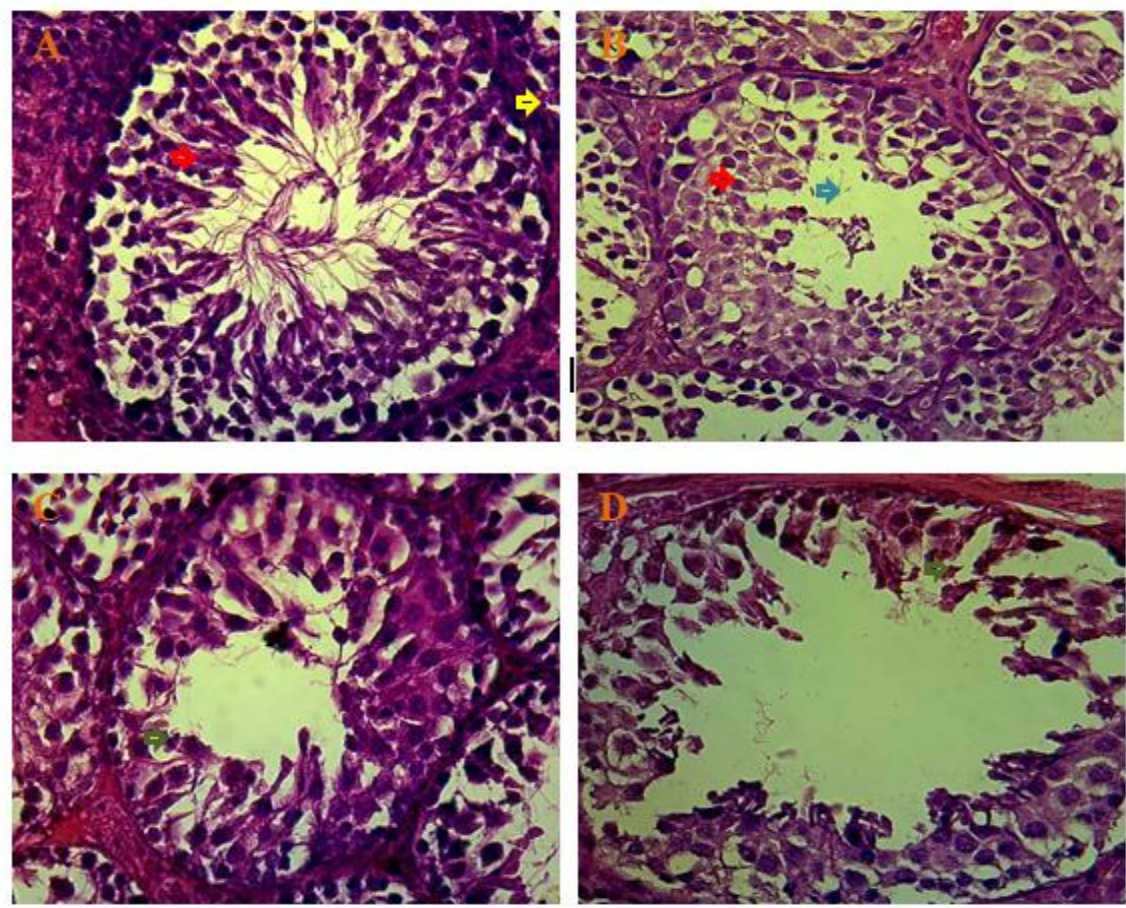

Gambar 1. Hasil skoring histopatologi tubulus seminiferus mencit dengan potongan melintang, menggunakan pewarnaan HE.
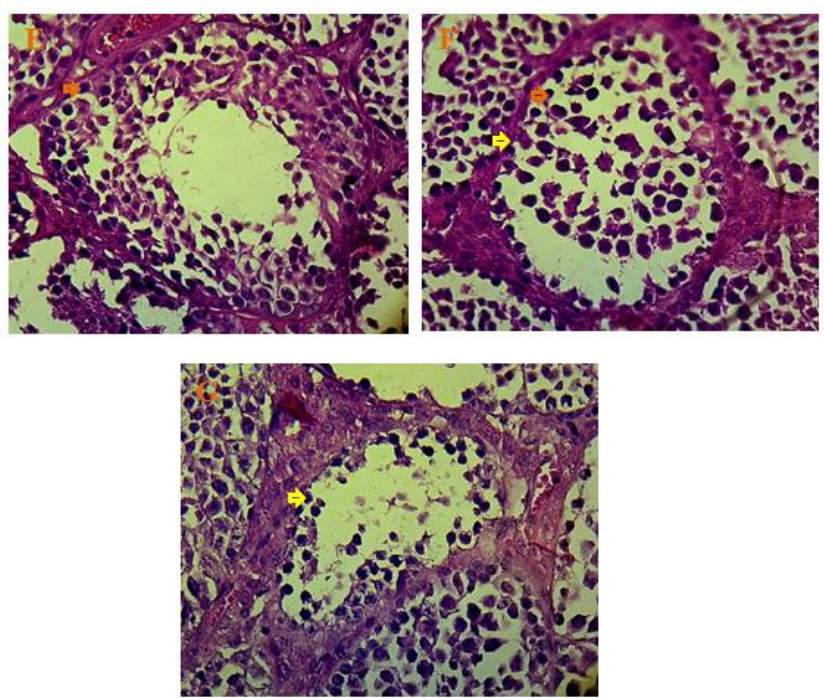

Gambar 2. Hasil skoring histopatologi tubulus seminiferus mencit dengan potongan melintang, menggunakan pewarnaan HE dengan perbesaran 400x.

Keterangan : ( ) )spermatogonia; ( Dspermatosit.

tubulus, sedikit spermatid tua); $\mathrm{C}$ menunjukan skor 7 (tidak ada spermatozoa, tidak ada spermatid tua, banyak spermatid muda) dan D menunjukan skor 6 (tidak ada spermatozoa, tidak ada spermatid tua, sedikit spermatid muda); Perbesaran mikroskop 400x.

Gambar E menunjukan skor 5 (tidak ada spermatozoa atau spermatid, banyak spermatosit); F menunjukan skor 4 (tidak ada spermatozoa atau spermtid, dan sedikit spermatosit); G menunjukan skor 3 (hanya spermatogonia).

\section{Pembahasan}

Berdasarkan hasil penelitian yang diakibatkan oleh pemberian jamur Fusarium graminearum pada mencit jantan de- 
ngan berbagai pengenceran yang diberikan secara per oral secara keseluruhan menunjukan bahwa spora jamur Fusarium graminearum dapat menurunkan jumlah sel spermatogonium, spermatid muda, spermatid tua dan spermatosit bahkan dapat pula menghilangkan spermatozoa.

Maka hasil penelitian terhadap paparan jamur Fusarium graminearum pada kelompok perlakuan P1, P2, dan P3 dibanding dengan kelompok perlakuan P0 ditemukan penurunan sel spermatogonium, spermatosit, spermatid dan spermatozoa. Pada P1 dengan jumlah spora yang paling rendah yaitu $228 \times 10^{6} \mathrm{spora} / \mathrm{ml}$ ditemukan penurunan sel spermatogonium, spermatosit, spermatid dan spermatozoa, P1 berbeda nyata dengan $\mathrm{P} 0$, tidak terjadi penurunan yang signifikan diduga karena toksisitas jamur Fusarium graminearum pengenceran $10^{2}$ tersebut memiliki jumlah spora yang paling rendah dibanding kelompok perlakuan yang lain. Hasil penelitian didapatkan bahwa P3 dengan paparan jamur Fusarium graminearum dengan jumlah $228 \times 10^{8}$ spora/ml mengakibatkan penurunan pada seluruh sel spermatogonium, spermatosit, dan spermatid sampai menghilangkan spermatozoa.

Hal ini sejalan dengan Nainggolan (2017) yang menyatakan, bahwa jamur fusarium graminearum terbukti dapat menyebabkan atau memicu terjadinya perubahan fisiologis spermatozoa mencit yang ditandai dengan penurunan fungsi dari membran plasma spermatozoa. Pemicu terjadinya perubahan fisiologis spermatozoa mencit adalah stress oksidatif. Stress oksidatif adalah salah satu faktor yang dapat menyebabkan menurunnya daya fertilitas pada spermatozoa selama masa penyimpanan pada epididimis.

Mayosita (2017) menyatakan bahwa, pemberian jangka panjang fusarium gramineaum dapat mengakibatkan gangguan reproduksi pada organ reproduksi jantan dengan sasaran utamanya testis sebagai tempat proses spermatogenesis berlangsung. Tingginya tingkat pembelahan atau replikasi menjadikan mitokondria sel germinal epitelium pada testismembutuhkan konsumsi oksigen yang tinggi untuk produksi ATP sebagai energi pada proses sintesis protein spermatozoa. Keberadaan ZEN dan DON di dalam tubuhmengakibatkan jumlah antioksidan intrasel tidak mampu menetralisir radikal bebas yang menyebabkan penurunan jumlah spermatozoa melalui peroksidasi lipid pada sitoplasma yang kaya asam lemak tak jenuh, akibatnya muncul stress oksidatif. Stres oksidatif dapat menyebabkan kerusakan jaringan testis terutama tubulus seminiferus sehingga dapat menghambat sintesis DNA dan RNA oleh sel spermatosit.Dengan demikian, ZEA dan DON dapat menganggu proses spermatogenesis yang bertindak sebagai radikal bebas, sehingga berpengaruh terhadap pembentukan struktur maupun fungsi protein menentukan kontinuitas dan kualitas produksi spermatozoa.

\section{Kesimpulan}

Berdasarkan hasil penelitian ini, maka dapat disimpulkan bahwa scoring tubulus seminiferusse telah pemberian $0,25 \mathrm{ml}$ suspense jamur Fusarium graminearum dengan beberapa jumlah spora dan didapatkan spora tertinggi yaitu $228 \times 10^{8} \mathrm{spora} / \mathrm{ml}$ mengakibatkan penurunan jumlah sel spermatogenik (sel spermatogonium, spermatosit, spermatid dan spermatozoa) pada proses spermatogenesis.

\section{Daftar Pustaka}

Geraldo, M. F., D. J. Tessmann, and C. Kemmelmeier, 2004. Production Of Mycotoxins by Fusarium Graminearum Isolated From Small Cereals (Wheat, Triticale, and Barley) Affected with Scab Disease in Southern Brazil. Brazilian Journal of Microbiology. 37: 58-63.

Himedia. 2011. RS Medium Base. Himedia Laboratories [online]. Swastik Disha Bussines Park. India.

Johnsen, S. 1970. Testicular Biopsy Score Count a Method for Registration of Spermatogenesis in Human Testes: Normal Values and Results in 335 Hypogonadal Males. Hormones. 1: 225.

Maragos, C. 2010. Zearalenone Occurence and Human Exposure. World Mycotoxin Journal.

Maryam, R. 2007. Metode Deteksi Mikotoksin. J. Mikol. Ked. Indonesia. 7: $1-2$.

Mayosita, S. O. 2017. Efek Protektif Alumunium Silikat Terhadap Kualitas Spermatozoa, Integritas Membran 
Plasma dan Gambaran Histopatologi Tubulus Seminiferus yang Diinduksi Fusarium graminearum Pada Mencit Jantan (Mus musculus). Thesis. Fakultas Kedokteran Hewan. Universitas Airlangga. Surabaya.

Nainggolan, M. N. A. H. 2017. Potensi Activated Charcoal (Arang Aktif) Terhadap Integritas Membran Spermatozoa dan Gambar Histopatologis Tubulus Seminiferus pada Testis Mencit (Mus Musculus) yang dipapar Jamur Fusarium graminearum. Thesis. Fakultas Kedokteran Hewan. Universitas Airlangga. Surabaya.

Pahlevi, R. 2014. Penambahan Tepung Kulit Pisang Kepok Kuning (Musa Balbisiana) Sebagai Sumber Energi Dalam Ransum Terhadap Konversi Pakan Dan Pertambahan Berat Badan Ayam Pedaging Jantan. (Skripsi). Fakultas Kedokteran Hewan. Universitas Airlangga. Surabaya
Surtikanti, S. 2011. Hama dan Penyakit Penting Tanaman Jagung dan Pengendaliannya. Balai Taman Seleria. Seminar Nasional Taman Seleria 2011.

Thompson, R., T. Aveling, and R.B. Prieto. 2013. A new semi-selective medium for Fusarium graminearum, $F$. proliferatum, F. Subglutinans and F. Verticillioides in Maize Seed. South African Journal of Botany. 84: 94-101. Umiyasih, U., dan E. Wina. 2008. Pengolahan dan Nilai Nutrisi Limbah Tanaman Jagung. Wartazoa. 18(3):127-136.

Widiyono, I., P. P. Putro, Sarmin, P. Astuti, and C. M. Airin. 2011. Serum Estradiol and Progesterone Concentration, Vulval Apperance, and Expoliative Vaginal Cytology During Estrous Cycle in Bligon Goats. 